Segarra Montaner, Marta. Una topografia del ser: espacio y temporalidad en Henri Michaux. Sevilla, ediciones Alfar, 1992. 198 págs.

El libro de Marta Segarra Montaner, Una topografía del ser: espacio y temporalidad en Henri Michaux, nos acerca a uno de los grandes poetas de lengua francesa del siglo XX. A pesar de la peculiariedad de su abundante obra poética y pictórica, Michaux es un autor bien conocido en Francia, país en el que discurre gran parte de su larga vida. En España en cambio poco se sabe de su obra y las raras alusiones a su poesía proceden casi todas de Sudamérica en donde autores como Octavio Paz o Jorge Luis Borges mencionan a Michaux y favorecen, aunque escasamente, la difusión de su obra. Ante tales circunstancias debemos agradecer a la profesora Segarra Montaner el haber roto el silencio que pesaba sobre una obra cuya riqueza nos revela a lo largo de 185 páginas en las que selecciona numerosas citas del poeta Henri Michaux: a la labor descriptiva e interpretativa une una acertada labor antológica.

Lautréamont, el Surrealismo, Paul Valéry o algunos místicos como Ruysbroeck y Hello constituyen el telón de fondo de este poeta tan reticente a cualquier tipo de afiliación. Resulta innegable, sin embargo, la preocupación compartida por muchos poetas del siglo por el lenguaje, la palabra como instrumento del saber, del conocer. Como Yves Bonnefoy, Ponge, Saint John Perse, du Bouchet... Michaux se enfrenta al lenguaje poético como «l'acte et le lieu de la poésie», en su alcance ontológico. La topología del ser es una topología metafísica y es este paso de la imagen a la idea, de la imagen como «procedimiento de anclaje» que Marta Segarra intenta describir y descifrar, partiendo de la configuración de los espacios y de la temporalidad.

El apoyo metodológico elegido es el de al mitocrítica, muy especialmente Las estructuras antropológicas del imaginario de Gilbert Durand, del cual la autora es fiel seguidora. El propósito inicial es el de integrar el imaginario michaudiano en una misma construcción temática unitaria y universal. Claudio Guillén, entusiasta autor del prólogo a dicho estudio, nos invita a mantener cierta reserva ante la tentación de acatar dócilmente un conjunto totalizador de órdenes temáticos. Como bien dice el profesor Guillén, la interpretación antropológica y la creación literaria son actitudes radicalmente dispares.

La progresión del estudio no desmiente la opinión de Guillén ya que Marta Segarra es la primera en subrayar el alcance existencial del discurso michaudiano. Escribir para Michaux implica un recorrerse a sí mismo para penetrar en un "espacio interior» (l'espace $d u$ dedans) y para conocer y/o exorcizar el yo múltiple y ambiva- 
lente, este «je est un autre» del que hablaba Rimbaud y al que Michaux incansablemente vuelve en su poesía: «Il n'est pas un moi. Il n'est pas dix moi. Il n'est pas de moi. Moi n'est qu'une position d'équilibre». Este exilio interior descalifica cualquier intento de fijación en el espacio o en el tiempo de un cosmos ordenado. Escribir se convierte en un proceso de alienación ya que el lenguaje -incluso el poético- es inadecuado para transcribir la infinidad del ser. En este aspecto coincide plenamente con el sentir de su época, con esa funesta "fascinación" de la literatura de nuestro siglo por el lenguaje como fenómeno existencial al que alude Foucault.

Esta conciencia de los márgenes del lenguaje le induce a cultivar otros lenguajes como la música y la pintura, aspectos a los que alude Marta Segarra y que nos sugieren numerosos posibles trabajos relacionados con esta obra polifacética.

Marta Segarra con este estudio nos invita esencialmente a leer poesía, a entrar en poesía y a conocer la obra de un gran poeta de lengua francesa, y se lo agradecemos.

\section{BRIGITTE LEGUEN}

SENIFF, DenNis P. Antología de la Literatura Hispánica. Gredos, Madrid, 1992.

Empezaré pronunciándome favorablemente por todo trabajo que, como el que me ocupa, se presenta como medio de conocimiento panorámico, y sobre todo si es de la Edad Media, tan necesitada de la atención editorial.

Y continuaré recordando los riesgos que tal labor entraña, a los que el propio antologista se sabía sin duda expuesto, riesgos que se resumen en definitiva en lo siguiente: que no todo el mundo va a compartir sus criterios de selección, como yo mismo le reprocharé, ni aunque su obra fuese perfecta.

Que ésta lo sea no me atrevería yo a afirmarlo con rotundidad. Pero es indudable que tiene suficientes aspectos como para poder ser considerara como aceptable, como lo demuestran los siguientes detalles.

El primero de ellos es su presentación. Independientemente de la agrupación de los textos por su pertenencia a un siglo y, dentro de él, a un género, cosa que es absolutamente necesaria, cada uno de aquéllos viene presentado por una breve noticia en la que se incluyen la fecha de composición (con las reservas que el asunto exige, y entendiéndose que se trata de la que propone el editor del texto que se antologiza), la localización del manuscrito (siglas, biblioteca) y la mención de la edición de la que se ha tomado el texto que se presenta. Es decir que se dan todos los datos exigibles en un tipo de trabajo como éste. Pero, desde luego, no creo haber leído que se exponga por qué razón se ha elegido una u otra edición, por 